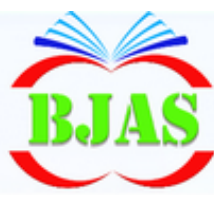

ISSN $1814-5868$
Available online at http://bjas.bajas.edu.iq

https://doi.org/10.37077/25200860.2020.33.2.09

College of Agriculture, University of Basrah
Basrah Journal

of Agricultural

Sciences

E-ISSN: 2520-0860

\title{
Organic Fertilization of Lucerne and the Following Oat Crop in Non- Irrigated Conditions
}

\author{
Viliana Vasileva ${ }^{1 *}$ \& Ognyan Kostov ${ }^{2}$
}

\author{
${ }^{1}$ Institute of Forage Crops, 89 “General Vladimir Vazov" Str., 5800 Pleven, Bulgaria \\ ${ }^{2}$ Nexus Technology Consultancy, Kuala Lumpure, Jalan Ampang 27, Malaysia \\ *Corresponding author e-mail: viliana.vasileva@gmail.com \\ Received 2 July 2020; Accepted 4 September 2020; Available online 20 October2020
}

\begin{abstract}
Conventional agriculture created ecological and sociological problems worldwide. Practicing organic agriculture need profitable crop such as lucerne, no tillage to destroy the soil structure, usage of natural symbiotic $\mathrm{N}_{2}$ fixation to support nutrition and reduce damages from climatic changes such as droughts and also to supply animals for food. The efficiency of manure fertilization for the production of forage, seeds and root mass after four years of lucerne cultivation was examined in the field experiment,in addition their effect on the following crop such as oat. The trial was performed in the Institute of Forage Crops, Pleven, Bulgaria on leached chernozem soil subtype without irrigation. The well matured cattle manure in the following doses was used: dose $1-20.7$ t.ha ${ }^{-1}$ corresponding to $70 \mathrm{~kg} \mathrm{~N}$. ha ${ }^{-1}$ (active substance); dose 2 - 41.5 t. ha ${ }^{-1}$ corresponding to $140 \mathrm{~kg} \mathrm{~N}$. ha ${ }^{-1}$ and dose $3-62.1 \mathrm{t}^{-h^{-1}}$ corresponding to $210 \mathrm{~kg} \mathrm{~N} \mathrm{ha}^{-1}$. It was found that, the highest organic fertilizer use efficiency (153.16) was found in lucerne for forage at a dose of $20.7 \mathrm{t}^{\mathrm{h} \mathrm{ha}} \mathrm{h}^{-1}$. The largest differences in fertilization efficiency depending on the dose were reported in lucerne for forage (1.9 and 2.8 times). The highest efficiency of manure fertilization for root mass accumulation was reported at a dose of $20.7 \mathrm{t}$. ha ${ }^{-1}$. The results showed that lower doses of manure can contribute to obtain a high yield of forage, straw, roots and seeds from lucerne. This has a positive effect on grain and straw and also to the following crop such as oat. Organic farming clearly indicated the advantages for both yields and environmentally friendly agriculture and reduction of environmental stresses.
\end{abstract}

Keywords: Manure, Organic fertilization, Efficiency coefficients, Lucerne, Drought, Environmental stress.

\section{Introduction}

Recently humans are facing many agricultural, environmental and climatic challenges. Conservation of soil fertility under agricultural usage depends on many factors such as maintaining of organic matter of soil, biological, chemical and physical properties of soil, symbiotic and non-symbiotic nitrogen fixation, reduction of soil erosion, avoiding environmental stress factors such as droughts and flooding's, the stability of soil and unsustainability of yields. These depend on climatic conditions, type of agriculture, type of plant, microbiological processes in soil with special attention to natural symbiotic and non-symbiotic $\mathrm{N}_{2}$-fixation (Yadav et al., 2018; Kostov \& Iordanov, 2019). Also Vasileva et al. (2011) and Vasileva \& Kostov (2015, 2018) pointed out the importance of water deficiency on development and yield of lucerne. National Sustainable Agriculture Coalition (2019) and Magdoff (2001, 2004) recommended urgently to help farmers to 


\section{Vasileva \& Kostov/ Basrah J. Agric. Sci., 33(2): 106-114, 2020}

meet challenges with severe historical droughts.

National Sustainable Agriculture Coalition (2019) also pointed out that there is an urgent need to help producers to meet challenges with droughts. Many of the practices that contribute to the overall strategies to solve these problems are well known as intensive use of cover crops, reduce tillage and widely develop ecological agriculture.

Lucerne is important for agriculture and environment because of its ability to fix atmospheric $\mathrm{N}_{2}$, stop soil erosion, deliver food for animals, maintain soil organic matter, thus have a great contribution for sustainable agriculture and supplying food for animals (Kertikova, 2008; Yadav et al., 2018; Kosev \& Kertikova, 2019). The soil used in this experiment have the active natural population for symbiotic $\mathrm{N}_{2}$ fixation bacteria thus can minimize mineral nitrogen application by using organic fertilizers and support yield formation of the following crop (Vasileva \& Kostov, 2015). One of the core philosophies of organic production systems is the development of healthy and productive soil that provides essential nutrients for plant growth, supports diverse and active soil biotic communities and balances the entire farm ecosystem (Mader et al., 2002; Goss et al., 2013).

The most used characteristic in agronomy are the quantity and quality of yield. There is a lack of knowledge to use more sensitive indicators for assessing fully efficiency of organic fertilization such as application of manure to support mitigation of climatic changes and emerging bio based economy.

Yensen et al. (2012) experimentally found that total $\mathrm{N}_{2} \mathrm{O}$ fluxes from legumes and $\mathrm{N}$ fertilized system vary enormously from 0.03 7.09 and $0.09-18.16 \quad \mathrm{~kg} \quad \mathrm{~N}_{2} \mathrm{O} \quad \mathrm{N} \quad \mathrm{ha}^{-1}$, respectively. Many studies showed significant lose from denitrification when working with mineral nitrogen (Kostov \& Van Cleemput, 2019). Life cycle energy balance of legume based rotation also can assist to lower agrochemicals for crop protection, reducing pathogens and pests and assist for weed control and wind water erosion. Organic fertilization of legumes such as lucerne can contribute to reduce the emission of carbon dioxide $\left(\mathrm{CO}_{2}\right)$, nitrous oxide $\left(\mathrm{N}_{2} \mathrm{O}\right)$, methane $\left(\mathrm{CH}_{4}\right)$ and ozone $\left(\mathrm{O}_{3}\right)$ depending on soil quality, presence of other species and climatic conditions. Crop response to applied nutrients is a global phenomenon.

The purpose of this study was to assess the efficiency of manure fertilization on the production of forage, seeds and root mass after four years of lucerne cultivation and their effect on the following crop production such as oat.

\section{Materials \& Methods}

The experiment was carried out in the experimental field of the Institute of Forage Crops, Pleven, Bulgarian Agricultural Academy by using the leached chernozem soil subtype. The trial was without any irrigation. Lucerne variety Victoria was sown at sowing rate of $30 \mathrm{~kg} \cdot \mathrm{ha}^{-1}$. Plots size was 10 $\mathrm{m}^{2}$. The experiment was carried out using 4 replications. The well matured cattle manure in the following doses was used: a) $20.7 \mathrm{t}^{\mathrm{ha}} \mathrm{ha}^{-1}$; b) $41.5 \mathrm{t}^{\mathrm{ha}} \mathrm{a}^{-1}$; c) $62.1 \mathrm{t} \cdot \mathrm{ha}^{-1}$. Phosphorous was applied as triple super phosphate at doses of $300 \mathrm{~kg} \mathrm{ha}^{-1}$ for all treatments. Potassium was applied as potassium chloride at dose of 150 $\mathrm{kg} \mathrm{ha}^{-1}$ for all treatments. The soil had the following agrochemical characteristics (Table 1). The used manure had the following agrochemical characteristic on dry matter basis (Table 2). 


\section{Vasileva \& Kostov/ Basrah J. Agric. Sci., 33(2): 106-114, 2020}

For manure we accepted mineralization percentages based on the total N. It was $46 \%$ for five years from the initial $\mathrm{N}$ in the manure (www.compostingcouncil.org; www.ohioline. osu.edu; www.agriculture.pordue.edu. $)$.

Efficiency coefficients were calculated as follows: forage yield/manure amount applied; seeds yield/manure amount applied; roots yield/manure amount applied and straw yield/manure amount applied and grain yield/manure amount applied (Bowen \& Zapata, 1991). The obtained data were statistically processed by using the SPSS 13.0 software program.

Climatological and meteorological characteristic of the area where two field experiments were carried out as follow: Climate expressed with strong continental character. Winter is cold with minimal raining, summer is hot with very often and sometimes very long lasting droughts, very hot during summer months and with strongly expressed colds during winters. Temperature sum for the period for air is over $10^{\circ} \mathrm{C}$, it is $3200-3400^{\circ} \mathrm{C}$ but for a period of over $5^{\circ} \mathrm{C}$ is about $400^{\circ} \mathrm{C}$. The lowest winter temperatures during the winter with snow cover, usually achieved up to $20-25^{\circ} \mathrm{C}$ but it can be seen late winter worming in February thus stimulating weak growth of grasses-forage mixtures. Duration of without freezing/chilly weather is about 200 days. The mean data for the beginning of hot (over $10^{\circ} \mathrm{C}$ ) weather is in April. As a result area have relatively cool spring. During summertime have been registered for many years (6-7 years) typical summer temperatures but sometimes temperatures can be very high and over $40^{\circ} \mathrm{C}$. Autumn is coming in September with slow reduction of temperatures with the lowest values in mornings and evenings. Usually dominating are west windiness $\left(1.9 \mathrm{~m} . \mathrm{s}^{-1}\right)$ which is typical for months March and April thus they dry surface layers of the soils. As a result it can be established lower germination rate especially for perennial leguminous grasses.

Rainfall was not regularly distributed which increase the harmful effect of yields to agricultural crops from droughts. Droughts start from the beginning of May to beginning of September.

\section{Results \& Discussion}

The obtained results for forage showed a slight increase of the yield from the increasing amount of applied manure, i.e. $3.97 \%$ at a dose of $41.5 \mathrm{t}^{-h^{-1}}$ compare to the first dose of 20.7 t.ha $^{-1}$, to $5.95 \%$ at the experimented highest dose of 62.1 t.ha $^{-1}$. Efficiency coefficients demonstrated significant reduction of the values from 153.16 to $54.09 \%$ (Table 3). This reduction of efficiency means that this amount of manure is too high and cannot stimulate the efficiency of applied manure and natural $\mathrm{N}_{2}$-fixation in these field conditions of low soil water content (Lodeiro et al., 2000; Vasileva \& Kostov, 2010). The next experimented dose of 41.5 t.ha $^{-1}$ showed an even higher reduction of the coefficient for forage. It can be concluded that higher doses of applied manure very slightly $(5.95 \%)$ increase the yield but significant decrease efficiency of applied organic fertilization. The reason for this decrease in efficiency is the long lasting dry conditions during the early spring and summer and weak raining in this area. It can be expected that natural symbiotic $\mathrm{N}_{2}$-fixing Rhizobium bacteria cannot deliver enough $\mathrm{N}$ to plant. Nodulation was poor (data are not shown). During drought condition manure is having stronger water holding capacity as compared to the soil and cannot deliver water to lucerne due to the drought. The 


\section{Vasileva \& Kostov/ Basrah J. Agric. Sci., 33(2): 106-114, 2020}

experimented second and third doses slightly increased the yield.

When building organic farming and maintaining high and sustainable yields, the prevailing concept in the literature is that in order to increase the level of organic matter in the soil, especially high (30-130 t. ha-1) doses of organic fertilizer should be applied (Raviv et al. 2004). Imported nitrogen with organic fertilizers is in organic form and does not cause soil toxicity, and does not reduce the amount of biological nitrogen fixation of freeliving soil nitrogen-fixing microorganisms also, because it slowly and in sync with plant development releases mineral nitrogen. In this way it permanently increases, both, the fertility and quality of the soil.

Regarding of the other parameters of yield such as seeds showed the tendency to decrease the coefficient of efficacy with the increase of doses of manure. Roots and nodules are very important for legumes because they supply naturally fixed nitrogen from the air. Data showed an increase of at dose of 41.5 t.ha $^{-1}$ with $12.6 \%$. The highest experimented dose of manure (62.1 t.ha-1) demonstrated that decrease of root biomass coefficients is very high. It can be concluded that increasing of the dosages of applied manure is not efficient and significant decrease efficiency. Very high level of nitrate nitrogen in matured manure, which can reduce natural $\mathrm{N}_{2}$-fixation of nodules was considered as a possible reasons for that. Also manure had very low total $\mathrm{N}$ of $0.72 \%$, despite of very good $\mathrm{C} / \mathrm{N}$ ratio of 20.8 .

Results from the following crop oat assessed for grain yield and straw yield are shown in table (4). The reduction of efficiency coefficients in grain from oats is $49.87 \%$ after lucerne for forage and $51.18 \%$ after lucerne for seeds at a dose of 41.5 t.ha ${ }^{-1}$. At dose of $62.1 \mathrm{t}^{-h a^{-1}}$ the reduction of grain yield of oat after lucerne for forage was $66.75 \%$ but after lucerne for seeds was $68.05 \%$. The efficiency coefficients for straw after lucerne for forage also showed reduction of $49.78 \%$ for a dose of 41.5 t.ha ${ }^{-1}$ and $48.3 \%$ reduction after lucerne for seeds. At a dose of 62.1 t.ha $^{-1}$ manure the reduction was much higher: after lucerne for forage was $64.83 \%$ and after lucerne for seeds was $66.80 \%$.

In the case of lucerne for forage with increasing fertilization doses, the efficiency of using the fertilizer for oat straw production decreased by $49.78 \%$ units per dose of $140 \mathrm{~kg}$ $\mathrm{N} \mathrm{ha}^{-1}$ and by 64.83 units per dose of $210 \mathrm{~kg}$ N. ha ${ }^{-1}$.

Regarding the yield of oats after the predecessor of lucerne for forage, the coefficient of efficiency of fertilizer use was found very high (from 93.49 to 281.16). After lucerne for seeds, the coefficient varies greatly. It is highest at the lowest dose of fertilizer. Al-Freeh et al. (2019) reported the increasing of yield grain after treatment of oat with biofertilizers.

Increasing straw yields after lucerne for fodder is small, the coefficient of efficiency of fertilizer use decreases with increasing doses of fertilizer. In the case of grain, the increase in yield is also insignificant, but the coefficient of efficiency is high and also decreases with increasing doses of fertilizer, especially at the highest dose.

Also manure during the maturation process accumulated a high amount of nitrate nitrogen which reduces natural symbiotic nitrogen fixation of this soil. The regular droughts (late spring and summer) inhibited natural $\mathrm{N}_{2}$ - 
Vasileva \& Kostov/ Basrah J. Agric. Sci., 33(2): 106-114, 2020

Table (1): Agrochemical characteristics of the soil.

\begin{tabular}{|c|c|c|c|c|c|c|c|}
\hline & Total C,\% & Total N, \% & $\begin{array}{c}\mathrm{P}_{2} \mathrm{O}_{5} \mathrm{mg} .100 \mathrm{~g}^{-1} \\
\text { soil }\end{array}$ & $\begin{array}{l}\mathrm{K}_{2} \mathrm{O} \text { mg. } 100 \mathrm{~g}^{-1} \\
\text { soil }\end{array}$ & $\begin{array}{c}\mathrm{pH} \\
\left(\mathrm{H}_{2} \mathrm{O}\right)\end{array}$ & $\begin{array}{c}\mathrm{NH}_{4}-\mathrm{N}, \underset{\text { soil }}{\mathrm{mg}} \mathrm{N} \mathrm{kg}^{-1} \\
\text { soil }\end{array}$ & $\begin{array}{c}\mathrm{NO}_{3}-\mathrm{N}, \underset{\text { mg Noil }}{\mathrm{N}} . \mathrm{kg}^{-1} \\
\text { so }\end{array}$ \\
\hline Soil & 2.8 & 0.23 & 5.3 & 48.4 & 7.05 & 11.2 & 18.8 \\
\hline
\end{tabular}

Table (2): Agrochemical characteristics of the manure.

\begin{tabular}{|c|c|c|c|c|c|c|c|c|c|c|}
\hline & $\begin{array}{l}\text { Total C, } \\
\%\end{array}$ & $\begin{array}{l}\text { Total N, } \\
\%\end{array}$ & $\begin{array}{l}\mathrm{C}: \mathrm{N} \text { ratio } \\
20.8\end{array}$ & $\begin{array}{l}\text { Ashes, } \\
\%\end{array}$ & $\begin{array}{l}\mathrm{NH}_{4}-\mathrm{N}, 42.8 \\
\text { mg N. kg }{ }^{-1} \text { dry } \\
\text { manure }\end{array}$ & $\begin{array}{l}\mathrm{NO}_{3}-\mathrm{N}, \mathrm{mg} \\
\mathrm{N} . \mathrm{kg}^{-1} \text { dry } \\
\text { manure }\end{array}$ & $\begin{array}{l}\mathrm{K}_{2} \mathrm{O}, \mathrm{mg} 100 \\
\mathrm{~g} \text { dry manure }\end{array}$ & $\begin{array}{l}\mathrm{pH} \\
\left(\mathrm{H}_{2} \mathrm{O}\right)\end{array}$ & $\begin{array}{l}\text { Humic acid, } \\
\text { dry matter }\end{array}$ & $\begin{array}{l}\text { Fulvic acid, } \\
\text { matter }\end{array}$ \\
\hline Manure & 15 & 0.72 & 20.8 & 25.0 & 42.8 & 541.4 & 78.3 & 6.7 & 8.55 & 0.01 \\
\hline
\end{tabular}

Table (3): Forage yield for four years: forage, seeds and roots and efficiency coefficients of lucerne (Mean \pm SE).

\begin{tabular}{|c|c|c|c|}
\hline & $\begin{array}{l}\text { Manure: } 20.7 \text { t.ha }^{-1} \\
\text { corresponding to } 70 \mathrm{~kg} \mathrm{~N}\end{array}$ & $\begin{array}{l}\text { Manure: } 41.5 \text { t.ha }^{-1}, \\
\text { corresponding to } 140 \mathrm{~kg} \mathrm{~N}\end{array}$ & $\begin{array}{l}\text { Manure: } 62.1 \text { t.ha } \\
{ }^{1} \text { corresponding to } 210 \mathrm{~kg} \mathrm{~N}\end{array}$ \\
\hline Yield $\mathrm{kg} \mathrm{ha}^{-1}$ forage & $31.704 \mathrm{a} \pm 1.30$ & $32.964 \mathrm{~b} \pm 1.61$ & $33.592 \mathrm{ab} \pm 1.93$ \\
\hline Coefficient of efficacy: $\mathrm{kg}$ yield. $\mathrm{kg}^{-1}$ manure, $\%$ forage & 153.16 & 79.43 & 54.09 \\
\hline Yield kg ha-1 seeds & $444 \mathrm{ab} \pm 16.9$ & $555 \mathrm{~b} \pm 15.1$ & $600 \mathrm{~b} \pm 17.3$ \\
\hline $\begin{array}{l}\text { Coefficient of efficacy: } \mathrm{kg} \text { yield. } \mathrm{kg}^{-1} \text { manure, } \% \\
\text { seeds }\end{array}$ & 2.14 & 1.34 & 0.97 \\
\hline Yield $\mathrm{kg} \mathrm{ha}^{-1}$ roots & $5328 \mathrm{c} \pm 100.2$ & $6027 \mathrm{bc} \pm 96.9$ & $5550 \mathrm{c} \pm 113.0$ \\
\hline $\begin{array}{l}\text { Coefficient of efficacy: kg yield. kg. }{ }^{-1} \text { manure, } \% \\
\text { roots }\end{array}$ & 25.74 & 14.5 & 8.94 \\
\hline
\end{tabular}


Vasileva \& Kostov/ Basrah J. Agric. Sci., 33(2): 106-114, 2020

Table (4): Effect of predecessor lucerne on development of the following oat crop: Straw and grain (Mean \pm SE).

\begin{tabular}{|c|c|c|c|}
\hline & $\begin{array}{l}\text { Manure: 20.7 } \text { t.ha }^{-1} \text {, } \\
\text { corresponding to } 70 \quad \mathrm{~kg} \\
\text { N.ha }{ }^{-1}\end{array}$ & $\begin{array}{l}\text { Manure: } 41.5 \text { t.ha }{ }^{-1} \text {, } \\
\text { corresponding to } 140 \mathrm{~kg} \\
\text { N.ha }{ }^{-1}\end{array}$ & $\begin{array}{llll}\text { Manure: } & 62.1 & & \text { t.ha }^{-} \\
{ }^{1} \text { corresponding } & \text { to } & 210 & \mathrm{~kg} \\
\text { N.ha }^{-1} & & & \end{array}$ \\
\hline $\begin{array}{l}\text { Straw after lucerne for forage, } \mathrm{kg} . \mathrm{ha}^{-} \\
{ }^{1} \text { straw }\end{array}$ & $1390 \mathrm{a} \pm 20.4$ & $1398 \mathrm{a} \pm 19.3$ & $1468 \mathrm{ab} \pm 20.1$ \\
\hline $\begin{array}{l}\text { Coefficient of efficacy, } \mathrm{kg} \text { yield. } \mathrm{kg} \\
\text { manure- }{ }^{1}, \%\end{array}$ & 67.1 & 33.7 & 23.6 \\
\hline $\begin{array}{l}\text { Straw after lucerne } \\
\text { for seeds, } \mathrm{kg} \mathrm{ha}^{-1} \text { straw }\end{array}$ & $1239 b \pm 17.6$ & $1282 b \pm 15.8$ & $1235 b \pm 18.3$ \\
\hline $\begin{array}{l}\text { Coefficient of efficacy, kg yield. } \mathrm{kg} \\
\text { manure }{ }^{-1} \%\end{array}$ & 59.9 & 30.9 & 19.9 \\
\hline $\begin{array}{l}\text { Grain after lucerne for forage, } \mathrm{kg} . \mathrm{ha}^{-1} \\
\text { grain }\end{array}$ & $5820 \mathrm{c} \pm 11.0$ & $5850 \mathrm{c} \pm 11.4$ & $5806 \mathrm{c} \pm 12.4$ \\
\hline Coefficient of efficacy, kg. ha ${ }^{-1}$ grain, $\%$ & 281.2 & 141.0 & 93.5 \\
\hline $\begin{array}{l}\text { Grain after lucerne for seeds, } \mathrm{kg} . \mathrm{ha}^{-1} \\
\text { grain }\end{array}$ & $4956 \mathrm{~d} \pm 32.6$ & $4850 \mathrm{~cd} \pm 36.4$ & $4750 \mathrm{~cd} \pm 34.1$ \\
\hline Coefficient of efficacy, kg. ha ${ }^{-1}$ grain, $\%$ & 239.4 & 116.9 & 76.5 \\
\hline
\end{tabular}


fixation and reduce the yield in this area It can be concluded that efficiency coefficients are much more sensitive indicators as compared with yield and can be used as indicators to find the lowest and enough suitable dose of manure for application thus to result in higher yields.

\section{Conclusion}

The results clearly showed that, there is a need for more studies on efficient use of organic fertilizers in nitrogen-fixing plants. Organic agriculture is a very promising way for getting higher yields as well for the reducing the adverse effects of mineral fertilizers on climate change. The data also show the advantages of the nitrogen-fixing plants and the need for restructuring of the agriculture in the direction of obtaining nitrogen by the natural way through its fixation from the air and by combining organic with microbiological fertilizer._It is necessary to intensify research in details on the development of basic and advanced knowledge to ecological, low impute agriculture, agroecology, soil management, climatic changes, organic fertilization and methods and practices to be introduced in ecological agriculture. The used methods to use of efficiency coefficients for manure fertilization are reliable indicators to show the efficiency of applied organic agriculture. Organic agriculture in drought conditions cannot have good presentation and drought condition also suppress natural symbiotic $\mathrm{N}_{2}$ fixation. The manure produced by animals and lucerne as food to animals is useful and strongly connected in ecological agriculture. Lucerne is good predecessor for the cultivation of oat as the following crop. Healthy plants, healthy soil, healthy air, healthy humans have to be always in our mind to protect environment and people from any pollutions and the environmental stresses.

\section{Acknowledgment}

We are thankful to the Agricultural Academy, Bulgaria for the opportunity to conduct the experiment

\section{Conflicts of interest}

The authors declare that they have no conflict of interests.

\section{ORCID}

V. Vasileva:_http://orcid.org/0000-0002-1667-2333

O. Kostov: http://orcid.org/0000-0001-5602-7892

\section{References}

Al-Freeh, L. M., Alabdulla, S. A., \& Huthily, K. H. (2019). Effect of mineral- biofertilizer on physiological parameters and yield of three varieties of Oat (Avena sativa L.). Basrah Journal of Agricultural Sciences, 32, 8-25. https://doi.org/10.37077/25200860.2019.13

Bowen, G. D., \& Zapata, F. (1991). Efficiency in uptake and use of $N$ by plants. In: Proceeding series stable isotopes in plant nutrition, soil fertility and environmental studies. IAEASM 313/130, Vienna, Austria:

349-362. https://inis.iaea.org/collection/NCLCollectionStore/ _Public/22/089/22089591.pdf?r=1

Goss, M. J., Tubelleh, A., \& Goorahoo, D. (2013). A review of the use of organic amendments and the risk to human health. Advances in Agronomy, 120, 275-379.

https://europepmc.org/article/agr/ind601117263

Kertikova, D. (2008). The newest achievements in lucerne breeding in Bulgaria. In: Proceeding Breeding 08, 24-27 Nov. 2008, Novi Sad, Serbia, 509-512.

Kosev, V. \& Kertikova, D. (2019). [Environmental stability of alfalfa accessions in basic quantitative traits]. Rastenievadni nauki (Bulgarian Journal Crop Sciences), 56, 9-19. (In Bulgarian, Eng. Abs.).

Kostov, O. \& Iordanov, J. (2019). Combined resource utilization with integrated practices for creation land shaft town infrastructures to reduce reasons of climate changes. Bulgarian Journal of Soil Science, Agrochemistry Ecology, 53, 3-4. 
Vasileva \& Kostov/ Basrah J. Agric. Sci., 33(2): 106-114, 2020

https://www.cabdirect.org/cabdirect/abstract/20203 082650

Kostov, O. \& Van Cleemput, O. (2019). Some aspects of bio environmental problems and further of science and scientific policy in European countries. Bulgarian Journal Soil Sciences, 4, 99-115. https://zenodo.org/record/3566238\#.X4w35cIzbIU

Lodeiro, A.R., Gonzales, P., Hernandes, A., Balaque, L., \& Favelukes, G. (2000). Comparison of drought tolerance in nitrogen fixing and inorganic nitrogengrown common beans. Plant Sciences, 154, 31-41. https://doi.org/10.1016/s0168-9452(99)00246-0

Mader, P., Fliebach, A., Dubois, D., Gunst, L., Fried, P. \& Niggli, U. (2002). Soil fertility and biodiversity in organic farming. Science, 296, 1694-1697.

https://science.sciencemag.org/content/296/557 3/1694

Magdoff, F. (2001). Concept, components, and strategies of soil health in agro ecosystems. Journal of Nematology, 33, 169-172. https://www.ncbi.nlm.nih.gov/pmc/articles/PMC26 20515/pdf/169.pdf

Magdoff, F. (2004). Ecological agriculture: Principles, practices, and constraints. Renewable Agriculture and Food Systems, 22, 109-117. https://doi.org/10.1017/S1742170507001846

National Sustainable Agriculture Coalition (2019). Agriculture and Climatic Change: Policy Imperatives and Opportunities to Help Producers Meet the Challenge. Washington, D. C., 71pp. https://sustainableagriculture.net/wpcontent/uploads/2019/11/NSAC-Climate-ChangePolicy-Position_paper-112019_WEB.pdf

Raviv, M., Shlomit, M., Krasnovsky, A., \& Ziadna, H. (2004). Organic matter and nitrogen conservation in manure compost for organic agriculture. Compost Science and Utilization, 12, 6-10.

Vasileva, V., \& Kostov, O. (2010). Effect of mineral nitrogen fertilizing on some characteristics of alfalfa in conditions of water deficiency stress. Ecology and Future, 9 9, 23-27. https://www.academia.edu/20625478/ECOLOGY_AN D_FUTURE_VOL._IX_No_2

Vasileva, V. \& Kostov, O. (2015). Effect of mineral and organic fertilization on alfalfa forage and soil fertility. Emirates Journal Food Agriculture, 27, 1-10. https://doi.org/10.9755/ejfa.2015.05.288

Vasileva, V., \& Kostov, O. (2018). Performance of oats in response to preceding alfalfa on mineral fertilization versus organic manuring on Chernozem soil. Indian Journal Agriculture Sciences, 88, 416-419. http://epubs.icar.org.in/ejournal/index.php/IJAgS/articl e/view/78517

Vasileva, V., Kostov, O., Vasilev, E., \& Athar, M. (2011). Effect of mineral nitrogen fertilization on growth characteristics of lucerne under induced water deficiency stress. Pakistan Journal of Botany, 43, 2925-2928.

http://www.pakbs.org/pjbot/PDFs/43(6)/46.pdf

Yadav, A., Kumar, A., Prasad, R., Saxena, A., \& Dhalival, H. (2018). Microbiome in Crops: Diversity, Distribution and Potential role in Crops Improvements. In Prasad, R., Gill, S., \& Tuneja, N. (Eds.). Crop Improvement Through Microbial Biotechnology, Elsevier: 305-332. https://doi.org/10.1007/978-981-138805-7_4

Yensen, E. S., Peoples, M. B., Boddey, R. M., Gresshoff, P. M., Hauggaard-Nielsen, H., Alves, B. J. R., \& Morrison, M. J. (2012). Legumes for mitigation of climatic change and the provision of feedstock for biofuel and biorefineries. A review. Agronomy Sustain. Development, 32, 329-364. https://orgprints.org/20912/ 
Vasileva \& Kostov/ Basrah J. Agric. Sci., 33(2): 106-114, 2020

\section{التسميا العضوي للجت والمحصول اللاحق الشوفان في الظروف غير المروية \\ فيليانا فاسيليفا 1 وأوجنيان كوستوف 2 \\ 1معهد المحاصيل العلفية، 89 شار ع "الجنر ال فلاديمير فازوف، 5800 بلفن ، بلغاريا \\ 2نيكسوس للاستشار ات التكنولوجية، كو الالمبور, جالان أمبانغ 27, ماليزيا}

المستخلص: ادت الزر اعة التقليدية على مسنوى العالم الى مشاكل بيئية واجتماعية. ان اسلوب الزراعة العضوية يحتاج إلى الى التئ

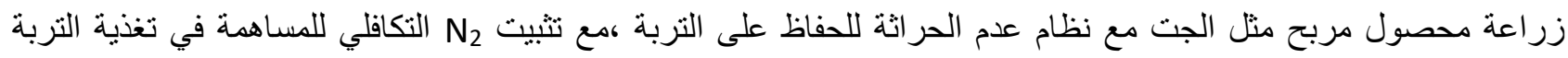

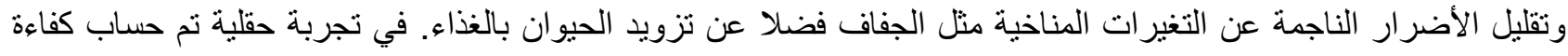

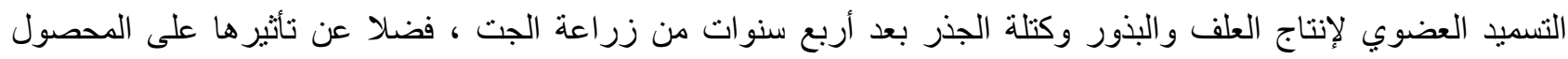

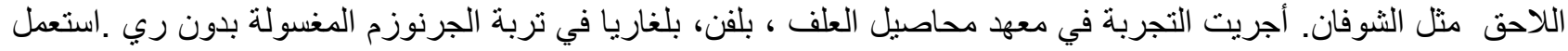

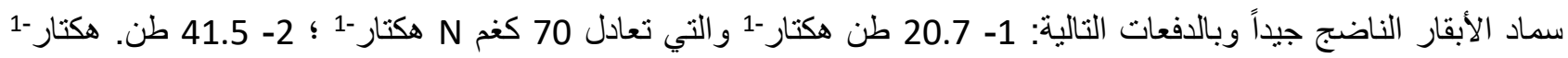

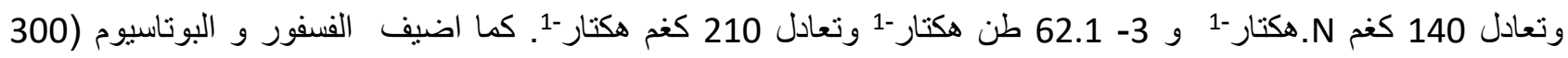

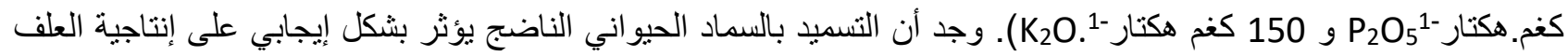

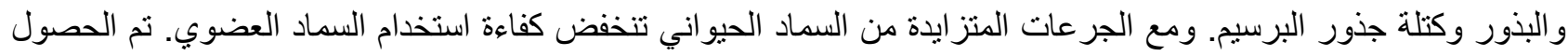

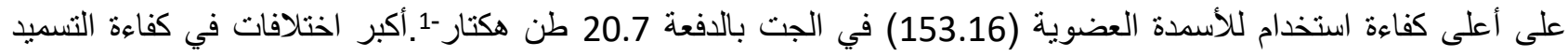

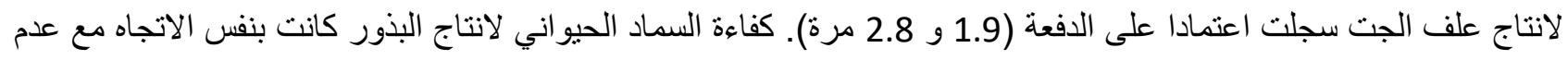

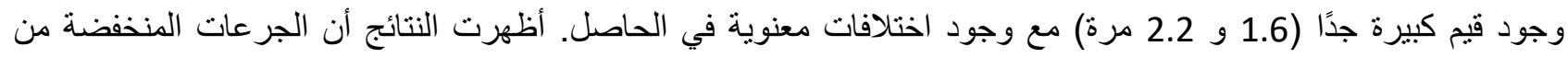

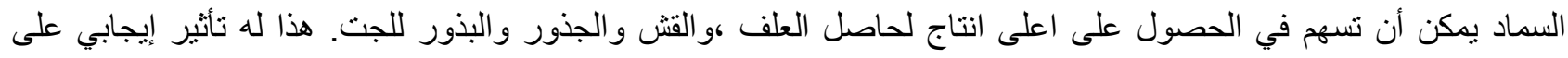

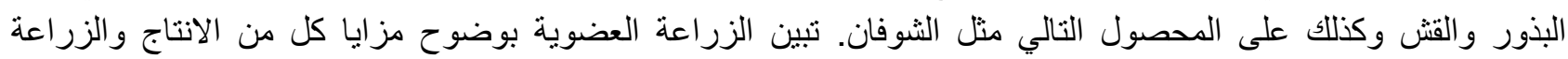
الصديقة للبيئة و الحد من الاجهادات البيئية.

الكلمات المفتاحية: السماد الحيواني، التسميد العضوي، معامل الكفاءة، الجت، الجفاف، الاجهاد البيئي. 